\title{
LEON POWOLNY. BOHATER WALKI O POLSKOŚĆ ŚLĄSKA OPOLSKIEGO CZY DEFRAUDANT?
}

\section{TYTUŁEM WSTĘPU}

Leon Powolny urodził się 7 lutego 1887 r. w Grabowie w Wielkopolsce'1. Mieszkał w Opolu. Był wybitnym działaczem na rzecz polskości Śląska Opolskiego, przez bardzo długi czas pełniąc odpowiedzialne funkcje w wielu organizacjach mniejszościowych. Był m.in. długoletnim dyrektorem Banku Ludowego w Opolu², tymczasowym przewodniczącym zarządu Związku Harcerzy Polskich w Niemczech ${ }^{3}$ (od 1927 r. prezesem Związku Harcerstwa Polskiego w Niemczech ${ }^{4}$ ), skarbnikiem Towarzystwa Pomocy Naukowej, członkiem Rady Naczelnej Związku Polaków w Niemczech [dalej: ZPwN], skarbnikiem Dzielnicy I ZPwN, członkiem zarządu „Nowin Codziennych”, , prezesem Towarzystwa Przyjaciół Harcerzy ${ }^{6}$, kierownikiem Oberschlesische Grundstücksverwertungsgesellschaft m.b.H.

Dr hab. Andrzes Szymański, prof. UO - Katedra Historii Państwa i Prawa oraz Doktryn Polityczno-Prawnych, Wydział Prawa i Administracji, Uniwersytet Opolski, ul. Katowicka 87 a, 45-060 Opole; e-mail: andrzej@kozle.pl; https://orcid.org/0000-0002-3504-0497

${ }^{1}$ R. Dermin, Działacze Związu Polaków w Niemczech na Ślasku Opolskim w kartotece opolskiego gestapo, „Studia Śląskie” 22 (1972), seria nowa, s. 242. Gazeta „Nowiny Codzienne” nr 201 z 1930 r. w tekście pt. Dyrektor Leon Powolny kandyduje do parlamentu Rzeszy (s. 1) podaje, że Powolny urodził się w1884 r.

${ }^{2}$ Zob. S. SENFT, Warunki niezależności ekonomicznej mniejszości polskiej na Ślasku Opolskim, „Pogranicze. Polish Borderlands Studies” 1 (3) (2015) s. 57-67.

${ }^{3}$ Zob. tekst pt. Dyrektor Leon Powolny kandyduje do parlamentu Rzeszy, „Nowiny Codzienne” 201 (1930), s. 1.

${ }^{4}$ Zob. https://issuu.com/zabrze.zhp/docs/zeszyt_historyczny2014 [dostęp: 29.04.2019].

${ }^{5}$ Czasopismo wydawane w Opolu w latach 1921-1939, od 1932 r. organ oficjalny ZPwN.

${ }^{6}$ E.J. OsmańczYK, Wista i Kraków to Rodto, Warszawa: Wydawnictwo Nasza Księgarnia 1985, s. 114 . 
W 1930 r. Konsulat Generalny RP w Bytomiu skierował prośbę do polskiej ambasady przy Watykanie, aby „poczynić ułatwienia p. dyrektorowi Powolnemu", który podczas swej bytności w Rzymie chciał być przyjęty przez papieża. W uzasadnieniu napisano: „P. Powolny jest dyrektorem Banku Ludowego w Opolu i odgrywa wybitną rolę w życiu mniejszości polskiej na Śląsku Opolskim"’7. Kandydował także w wyborach do parlamentu Rzeszy ${ }^{8}$.

Długo po opisanych w niniejszym tekście wydarzeniach, już podczas II wojny światowej ppor. Leon Powolny, ps. „Dobrzyński” stanął na czele struktur Związku Walki Zbrojnej (ZWZ) w tzw. „obwodzie rolniczym” Inspektoratu Opolskiego (kryptonim „Skorpion”), obejmującym powiaty opolski, strzelecki, oleski, kluczborski, dobrodzieński i prudnicki ${ }^{9}$. Powolny był jednocześnie członkiem sztabu Inspektoratu i jednym z zastępców jego komendanta. Dnia 19 maja 1943 r. Powolny - „Dobrzyński” został aresztowany, a 30 października 1944 r. ścięto go toporem $\mathrm{w}$ więzieniu w Brandenburgu ${ }^{10}$.

${ }^{7}$ Pismo Konsulatu Generalnego RP w Bytomiu do ambasady polskiej przy Watykanie z 5 maja 1930 r. (481/T/30), poufne, Archiwum Akt Nowych [dalej cyt.: AAN], Konsulat Generalny RP w Opolu [dalej cyt.: KGO], sygn. 2/482/0/4/153, k. 45.

${ }^{8}$ Zob. przypis nr 3.

${ }^{9}$ W. Kempa, Armia Krajowa na Opolszczyźnie (część pierwsza), [w:] https://www.magnapolonia. org/armia-krajowa-na-opolszczyznie-czesc-pierwsza/ [dostęp: 24.04.2019]; zob. także: http://www. dws-xip.pl/PW/formacje/pw2020.html [dostęp: 30.04.2019].

${ }^{10}$ Tamże. Zob. także H. Lehr, E.J. OsmańCZYK, Polacy spod znaku Rodła, Warszawa: Wydawnictwo Ministerstwa Obrony Narodowej 1972, s. 205 i 208-209 (tutaj zdjęcie listy ściętych w Brandenburgu z rubryką ,gemordet” - „zamordowani”); https://www.miejscapamieci.org/inne/mpc/ Memorial/mpa/show/mp-place/brandenburg-ciezkie-wiezienie-karne/ [dostęp: 29.04.2019]. M. Cygański w tekście pt. Hitlerowskie prześladowania przywódców i aktywu Związku Polaków w Niemczech w latach 1939-1945 („Przegląd Zachodni” 4 (1984), s. 34) stwierdził, że L. Powolny aresztowany został podczas drugiej fazy „Akcji Wrzesień” (Septemberaktion), czyli masowych aresztowań zasłużonych działaczy polskich na Śląsku Opolskim, które miały miejsce w dniach 11-12 września 1939 r. Ujęto go w grupie dyrektorów Banków Ludowych z Opola, Raciborza, Bytomia i Koźla. W podobny sposób pisał o tym S. Senft: „Wrześniowa fala aresztowań czołowych działaczy ZPwN i organizacji afiliowanych dotknęła przeszło 180-osobową kadrę spółdzielców, w tym wszystkich dyrektorów i przewodniczących rad nadzorczych w bankach. Różne były ich późniejsze losy, wielu z represjonowanych, wywiezionych bez wyroków sądowych do obozów koncentracyjnych (głównie Buchenwaldu) i ciężkich więzień już nie powróciło z miejsc kaźni, w tym dyrektorzy banków ludowych w Opolu (Leon Powolny), Raciborzu (Leon Nawrocki), Oleśnie (Wojciech Michałek), Gliwicach (Jan Śliwka). Niektórzy z aresztowanych spędzili w miejscach odosobnienia cały okres wojny, innych zwolniono, by poddać później ścisłemu nadzorowi gestapo [autor rozważa, czy mogło tu chodzić o L. Powolnego - zaznaczenie A.S.], przymusowo zaciągać do Wehrmachtu, wysiedlać poza Śląsk, konfiskując przy tym gospodarstwo" (SENFT, Warunki niezależności ekonomicznej, s. 57-67). Zob. także M. Choroś, Ł. JARCZAK, Ludzie i historia w nazwach ulic Opola, Opole: Wydawnictwo Instytut Śląski 2010, s. 97. W książce pt. Ulice Opola. Sylwetki zastużonych Opolan (Kuźniewski I [i in.], Opole: Opolskie Zakłady Graficzne 1971, s. 88), znajduje się informacja, że L. Powolny został w 1943 r. ścięty w więzieniu Plötzensee w Berlinie. 
W niniejszym artykule pragnę zasygnalizować pewien mniej znany epizod z życia Leona Powolnego i jego rodziny. M. Masnyk w książce pt. Dzielnica I Związu Polaków w Niemczech (1923-1939) odnosząc się do trudnej sytuacji Banku Ludowego w Opolu u progu lat 30-tych XX w. napisał: „Jedynie solidarna postawa zrzeszonych w nim członków uchroniła go od upadłości. Atmosferę wokół opolskiego BL skomplikowała ujawniona w kwietniu $1931 \mathrm{r}$. niegospodarność jej dyrektora, L. Powolnego. Kontrola finansowa wykazała, że Powolny „sprzeniewierzył" 41 tys. mk, z których do 18 V 1931 r. zwrócił zaledwie 11 tys. [...] Władze związku nie potrafiły zająć wobec Powolnego zdecydowanego stanowiska, ten zaś zgłaszał wobec $\mathrm{ZPwN}$ pretensje finansowe w wysokości 12 tys. mk, przy czym ZPwN skłonny był uznać tylko 7 tys." "11. Rzecz tak interesująca wręcz domagała się dokładniejszego nieco potraktowania tym bardziej, że w Archiwum Akt Nowych w Warszawie znajduje się zespół dokumentów dotyczący tej sprawy.

\section{MYSTERIUM INIQUITATIS LEONA POWOLNEGO}

Dnia 13 kwietnia 1931 r. Leon Malhomme de la Roche, konsul generalny Rzeczypospolitej Polskiej w Bytomiu, poinformował Poselstwo Polskie w Berlinie ${ }^{12}$, że Stanisław Spychalski, dyrektor opolskiego Banku Ludowego zakomunikował mu, iż Leon Powolny, drugi dyrektor tejże instytucji „nie wyliczył się przed bankiem z poważniejszych sum, wysokość których, jak dotychczas stwierdzono, sięga kwoty $38.000 \mathrm{RM}^{13}, 14$. Dnia 8 maja 1931 r. Poselstwo prosiło o nadsyłanie nowych wiadomości „co do niewyliczenia się przez dyrektora Leona Powolnego

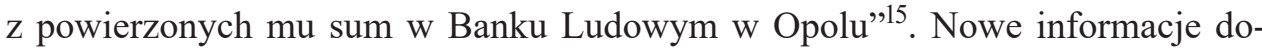
tyczące tej sprawy znalazły się w piśmie konsula z 18 maja $1931 \mathrm{r} .{ }^{16}$ „Nieścisłości kasowe" sięgnęły kwoty 41.000 RM z czego dyrektor Powolny spłacił już 11.000 RM. W najbliższym czasie miało być sprzedane auto Powolnego za 6.000 RM, a uzyskana kwota zostać miała przeznaczona na spłatę owych „nieścisłości”. Zarząd

\footnotetext{
${ }^{11}$ M. Masnyk, Dzielnica I Związku Polaków w Niemczech (1923-1939), Opole: Wyższa Szkoła Pedagogiczna 1994, s. 156.

${ }^{12}$ Dopiero w 1934 r. poselstwo polskie w Berlinie podniesione zostało do rangi ambasady.

${ }^{13}$ Reichsmarka, ,marka rzeszowa” - waluta niemiecka w latach 1924-1948, emitowana przez Bank Rzeszy. W tekście używana jest także nazwa „mkn” lub „mk” - marka niemiecka lub marka.

${ }^{14}$ Pismo Leon Malhomme de la Roche, konsula generalnego RP w Opolu do Poselstwa RP w Berlinie z dnia 13 kwietnia 1931 r., (607/T/31), ściśle tajne, AAN, KGO, sygn. 2/482/0/4/153, k. 38.

${ }^{15}$ Pismo Poselstwa RP w Berlinie do konsula generalnego RP w Bytomiu z 8 maja $1931 \mathrm{r}$., (T. 1504/31), tajne, tamże, k. 39.

${ }^{16}$ Odpis pisma konsula Malhomme de la Roche do Poselstwa Polskiego w Berlinie z 18 maja 1931 r., (819/T/31), tajne, tamże, k. 49.
} 
Banku Ludowego w Opolu zamierzał w ciągu pół roku ściągnąć od dyrektora co najmniej 50\% zdefraudowanej kwoty. Comiesięcznie z jego wynagrodzenia potrącano 300 RM. Zamierzano w ten sposób osiągnąć 100\% zwrotu zobowiązań. Kolejny monit z Poselstwa w Berlinie do konsula Malhomme'a wysłano 11 czerwca 1931 r. Zaniepokojony dr Alfred Wysocki, poseł RP, prosił konsula o poświęcenie tej sprawie „bacznej uwagi, nie tylko pod kątem [...] uchronienia od strat materialnych bezpośrednio w tym wypadku zagrożonego Banku Ludowego w Opolu, ale i pod kątem moralnej oceny osoby p. Powolnego, który jest nie tylko dyrektorem banku [...], ale również zajmuje szereg wybitnych stanowisk w życiu społeczno-narodowym Śląska Opolskiego”. Poseł prosił także o przekazanie „poglądu na całość sprawy" i wniosków do Ministerstwa Spraw Zagranicznych w Warszawie ${ }^{17}$.

W odpowiedzi konsul stwierdzi1 ${ }^{18}$, że ,niemożliwe jest dalsze tolerowanie osoby p. Powolnego na wszystkich stanowiskach społecznych z uwagi na to, że to dyskredytuje moralnie te wszystkie towarzystwa, w zarządzie których p. Powolny zasiada”. Jednocześnie konsul zażądał od władz Dzielnicy I Związku Polaków w Niemczech ${ }^{19}$, aby wpłynęły na Powolnego, by ten zrzekł się wszystkich tego typu stanowisk. Zwiększenie presji planowano po zakończeniu kompleksowej kontroli w banku. Jednak Powolny zrezygnował na razie tylko z kandydowania do zarządu Związku Polskiej Młodzieży Katolickiej, pozostając nadal prezesem Związku Harcerstwa Polskiego w Niemczech, skarbnikiem Towarzystwa Pomocy Naukowej, skarbnikiem Dzielnicy I ZPwN, członkiem Rady Naczelnej ZPwN, członkiem zarządu „Nowin Codziennych”"20 i kierownikiem Oberschlesische Grundstücksverwertungsgesellschaft m.b.H. Sam konsul osobiście przekazał Powolnemu, że tych stanowisk zrzec się musi, ten jednak „nie poczuwał się do obowiązku dobrowolnego ustąpienia", pozostawało zatem tylko usunięcie go z zajmowanych funkcji.

Za niezastosowanie „sankcji moralnych” wobec Powolnego konsul Malhomme obwiniał ZPwN, który wobec winowajcy zajmował „stanowisko niezupełnie wyraźne" i „wykazywał tendencje do puszczenia płazem całej sprawy”, ponieważ Powolny miał w stosunku do Związku roszczenie finansowe w wysokości ok. 12.000 RM, które Związek był skłonny uznać tylko do wysokości 7.000 RM²1.

\footnotetext{
${ }^{17}$ Pismo Poselstwa Polskiego w Berlinie do konsula generalnego RP w Bytomiu z 11 czerwca 1931 r. (T/2245/31), tajne, tamże, s. 52.

${ }^{18}$ Pismo konsula generalnego RP w Bytomiu do Poselstwa Polskiego w Berlinie z 25 czerwca 1931 r. (1049/T/31), tajne, tamże, k. 54 n.

${ }^{19}$ Dzielnica I ZPwN z siedzibą w Opolu obejmowała tereny Śląska Opolskiego i liczyła ok. 5100 członków zrzeszonych w 104 kołach.

${ }^{20}$ Czasopismo wydawane w Opolu w latach 1921-1939, od 1932 r. organ oficjalny ZPwN.

${ }^{21}$ Pismo konsula generalnego RP w Opolu do Poselstwa Polskiego w Berlinie z 25 czerwca 1931 r. (1049/T/31), tajne, AAN, KGO, sygn. 2/482/0/4/153, k. 54 n.
} 
Ponadto „p. Powolny sam i jego przyjaciele rozpuszczali pogłoski, że to Związek doprowadził [go] do takiej sytuacji, w jakiej się on obecnie znalazł”. Zwracano jednak uwagę, że pretensje Powolnego to najwyżej 12. 000 RM, zaś suma defraudacji to $41.000 \mathrm{RM}$, wobec czego wszelkie tłumaczenia tegoż są pozbawione podstaw wobec niemożliwości wydania całej brakującej kwoty na rzecz Związku.

W tej sytuacji konsul generalny wezwał do siebie kierownika Dzielnicy I ZPwN i „wymógł na nim” przyrzeczenie, że zostaną zbadane wszystkie pretensje finansowe Powolnego, a następnie Związek porozumie się z Bankiem Ludowym w Opolu „W kierunku przejęcia przez Związek uznanych przezeń pretensji p. Powolnego". Konsul ponowił także żądanie usunięcia defraudanta $\mathrm{z}$ wszystkich funkcji, co zostało przyrzeczone. Nie zwolniono Powolnego z pracy w banku, jednak został on odsunięty od kontaktu $\mathrm{z}$ pieniędzmi. $\mathrm{Z}$ jego pensji potrącano comiesięcznie pewną kwotę na spłacenie zadłużenia i była to w zasadzie jedyna gwarancja pokrycia strat, poniesionych przez bank. Jednocześnie konsul zażądał, aby „wszystkie udziały przedsiębiorstw polskich, zapisane dotychczas fikcyjnie na p. Powolnego, zostały niezwłocznie przepisane na inną osobę"22.

Dnia 25 września 1931 r. konsul generalny RP w Opolu przesłał do Ministerstwa Spraw Zagranicznych w Warszawie informację o wynikach rewizji w opolskim Banku Ludowym ${ }^{23}$. Według niej „podstawy [...] Banku są zdrowe i Bank cieszy się wśród klientów dobrą opinią”. Odnośnie do „sprzeniewierzenia kasowego" dokonanego przez Leona Powolnego, nadal wywierano naciski w celu zrzeczenia się przez niego honorowych stanowisk - bez większych sukcesów. Powodem był brak „cywilnej odwagi czynników lokalnych”. Mimo wszystko nie zdecydowano się na zwolnienie Powolnego z posady bankowej, gdyż „natychmiastowe usunięcie [...] oraz ujawnienie dokonanej malwersacji może wywołać niepokój wśród klienteli Banku, co w obecnych czasach kryzysu finansowego w Niemczech mogłoby i dla nas samych wywołać [...] poważne trudności natury finansowej, powodując wielce prawdopodobny run na Bank Ludowy"24. Jak już wyżej wspomniano, defraudantowi ściągano comiesięcznie $300 \mathrm{RM}$ z pensji na pokrycie niedoboru kasowego. Ponadto Powolnego odsunięto zupełnie od kontaktu z pieniędzmi, w związku z czym „nie ma obawy, aby dalszy pobyt p. Powolnego w Banku groził temu ostatniemu nowymi stratami” ${ }^{25}$. Wreszcie, liczono się z tym, że „p. Powolny posiada rodzinę i niemożliwe byłoby wyrzucać wymienionego bezzwłocznie na bruk”. Konsul uważał jednak, że sprawcę „niedoborów kasowych” należy po-

22 Tamże.

${ }^{23}$ Odpis pisma konsula generalnego RP w Opolu do Ministerstwa Spraw Zagranicznych w Warszawie, Wydział KI z 25 września 1931 r., ściśle tajne, numer nieczytelny, tamże, k. 57 n.

${ }^{24}$ Tamże.

${ }^{25}$ Tamże. 
ciągnąć do odpowiedzialności sądowej za popełnioną kradzież, winno to bowiem być przestrogą dla „działaczy mniej odpornych moralnie”. „Obawiam się jednak - pisał dalej konsul - że zbytnie kompromitowanie p. P. mogłoby być w obecnej chwili niewskazane i o tyle w dodatku niebezpieczne, że jest on prawie au courant [świadomy - A.S.] szczegółów akcji subwencyjnej prowadzonej przez nas"26. W piśmie z 30 września 1931 r. konsul informował, że Leon Powolny zobowiązał się do zrzeczenia się funkcji honorowych, co miał uczynić na piśmie ewentualnie listami poleconymi skierowanymi do poszczególnych instytucji. Zrzeczenia się miały być motywowane nadmiarem pracy. Do końca września pisma takie wysłał Powolny do centrali ZPwN w Berlinie oraz do Związku Polskich Towarzystw Szkolnych z siedzibą w tym samym mieście. Oba pisma zawierały zrzeczenie się godności honorowych ${ }^{27}$.

Przeciwko szybkiemu oddawaniu sprawy Powolnego do sądu niemieckiego „póki pełni on jeszcze tyle funkcyj honorowych" - opowiadał się także dr Roman Staniewicz, dyrektor Departamentu Konsularnego MSZ w Warszawie. W piśmie, skierowanym 30 września 1931 r. do konsula generalnego RP w Opolu ${ }^{28}$ wskazywał, że będzie to możliwe „po wyjściu sprawy z obecnego stadium”, po uprzednich konsultacjach z Poselstwem RP w Berlinie.

Aresztowanie Powolnego nastąpiło najprawdopodobniej w ostatnich dniach września 1932 r., gdyż niemieckie gazety lokalne z 30 września i 1 października tego roku („Allgemeiner Lokalanzeiger”, „Oberschlesische Volksstimme”, „Ostdeutsche Morgenpost”) „nadzwyczaj żywo" zajmowały się tym faktem ${ }^{29}$. Zamieszczono w nich obszerne artykuły w ,naczelnych” miejscach pod sensacyjnymi tytułami. Trudną sytuację Banku Polskiego łączono w nich jednoznacznie z defraudacją dokonaną przez dyrektora Powolnego, ,podnosząc jego życie ponad stan"30.

Dnia 8 października 1932 r. do konsula generalnego RP w Opolu zgłosił się niejaki Wolf, obrońca aresztowanego L. Powolnego, przyjął go attache Staniszewski. Wolf oświadczył, że zwraca się do konsula jako do osoby, której los Powolnego, jako działacza narodowego i gospodarczego nie może być obojętny. Ponadto konsul jako osoba, „która Powolnego darzyła swego czasu sympatią, trzymając nawet do

26 Tamże.

${ }^{27}$ Odpis pisma konsula generalnego RP w Bytomiu do Ministerstwa Spraw Zagranicznych w Warszawie, Wydział KI z 30 września 1931 r. (1584/T/31), tajne, tamże, k. 60.

${ }^{28}$ Pismo Ministerstwa Spraw Zagranicznych w Warszawie do konsula generalnego RP w Opolu z 30 września 1931 r. (K.I. 2370/8/31), tajne, tamże, k. 61.

${ }^{29}$ Pismo konsula generalnego RP w Opolu do Wydziału P. VI. Ministerstwa Spraw Zagranicznych w Warszawie z 6 października 1932 r. (1218/T/32), poufne, tamże, k. 64.

${ }^{30}$ Tamże. 
chrztu jego dziecko"31 z pewnością zechce pomóc zaaresztowanemu dyrektorowi, który zdaniem adwokata był oczywiście niewinny. Owa pomoc miałaby polegać na pośrednictwie w zdobyciu od polskich kół mniejszościowych od 6000 do 10000 RM na kaucję, po wpłaceniu której Powolny mógłby wyjść z aresztu. Attache Staniszewski powiedział Wolfowi, że Powolnego nie zna, a po środki na kaucję należałoby się zwrócić raczej do kolegów i znajomych aresztowanego, nie zaś do polskiego Konsulatu Generalnego. Adwokat delikatnie zasugerował, że „Powolny, który rzekomo udzielać musiał poza wiedzą Banku pożyczek Związkowi Polaków [w Niemczech] i innym instytucjom narodowym ${ }^{32}$, wobec opuszczenia go przez współrodaków i przyjaciół, będzie się starał wykazać, że wina nie jest wyłącznie jego". Mimo to powiedziano mu, że „sprawa ta Konsulat Generalny nic nie obchodzi”. Następnie Wolf udał się do Marquardta, dyrektora Banku Rolników w Opolu, którego konsul Malhomme uprzednio dyskretnie poinformował o swoim desinteressement $\mathrm{w}$ tej sprawie.

Dnia 9 listopada 1932 r., a więc w mniej więcej pięć tygodni po aresztowaniu L. Powolnego, do konsula generalnego RP Malhomme'a napisała żona defraudanta, Marta ${ }^{33}$. Prosiła ona, aby konsul, używszy „swoich wpływów” pomógł jej uzyskać „posadę nauczycielki w szkole mniejszościowej” w Niemczech, bowiem, będąc dotychczas na utrzymaniu męża, utraciła obecnie wszystkie środki do życia, wpadając w nędzę wraz z dziećmi. W kolejnym liście, datowanym na 21 listopada 1932 r. ${ }^{34}$ ponawiała swoją prośbę dowiedziawszy się, że konsul Malhomme ma niebawem opuścić Śląsk. Precyzowała także, że wolałaby otrzymać posadę na miejscu, bowiem będąc obywatelką niemiecką nie miała pewności, że uda jej się uzyskać zatrudnienie w Polsce. Sprawę tę konsul zrelacjonował Poselstwu Polskiemu w Berlinie ${ }^{35}$ wskazując, że uważa ułatwienie p. Powolnej znalezienia posady nauczycielskiej za „ogromnie wskazane”. Wskazywał, że nie miała ona pojęcia o machinacjach dokonywanych przez jej męża, a ich ujawnienie było

${ }^{31}$ Pismo konsula generalnego RP w Opolu do posła RP w Berlinie z 8 października 1932 r. (1243/T/32), tajne, tamże, k. 73. Konsul Malhomme uściślał w piśmie: „Powolny, gdy był otaczany powszechnym zaufaniem, ożenił się swego czasu z obywatelką polską z Poznańskiego, przyczep otrzymał ode mnie papierośnicę z dedykacją. Syna jego istotnie do chrztu trzymałem".

${ }^{32}$ Bank Ludowy w Raciborzu, Bank Rolników w Opolu, a z pewnością także Bank Ludowy w Opolu udzielały „niejawnych” subwencji Związkowi Polaków w Niemczech, zob. MasnYK, Dzielnica I Związku Polaków w Niemczech, s. 56.

${ }^{33}$ List żony L. Powolnego, Marty do konsula generalnego RP w Opolu z 9 listopada 1932 r., AAN, KGO, sygn. 2/482/0/4/153, k. 78 n.

${ }^{34}$ List żony L. Powolnego, Marty do konsula generalnego RP w Opolu z 21 listopada 1932 r., tamże, k. 82-83.

35 Pismo konsula generalnego RP w Opolu do Poselstwa Polskiego w Berlinie z 24 listopada 1932 r. (1418/T/32), tajne, AAN, KGO, sygn. 2/482/0/4/153, k. 84. 
dla niej ,zupełnie niespodziewanym ciosem”. Proponował nadanie jej posady nauczycielskiej w Westfalii lub w Prusach Wschodnich sugerując, aby Powolna występowała pod nazwiskiem panieńskim Kańtecka.

Jednak Poseł RP w Berlinie był przeciwny ,zatrudnieniu p. [Marty] Powolnej na jakimkolwiek terenie w Niemczech", skłonny był jednak do wystąpienia wobec władz krajowych o zatrudnienie jej w Polsce lub „na innych terenach emigracyjnych" 36 . Jednocześnie konsulat w Opolu prosił kilkakrotnie p. Powolną o dostarczenie świadectw ukończonych studiów i zaświadczeń z poprzedniej pracy w szkolnictwie. Ta jednak zwlekała uzależniając dalsze starania o uzyskanie posady nauczycielskiej od wyniku rozprawy sądowej przeciwko jej mężowi ${ }^{37}$. Jednak ostatecznie 25 marca 1933 r. konsul Bohdan Samborski, kierownik Konsulatu Generalnego w Opolu przesłał Poselstwu RP w Berlinie odpisy „świadectw szkolnych i nauczycielskich" Marty Powolnej wraz z podaniem skierowanym do Ministerstwa Wyznań Religijnych i Oświecenia Publicznego dwa dni wcześniej ${ }^{38}$. Konsul prosił Poselstwo o „wyrobienie dla niej posady nauczycielskiej”, gdyż Powolna „znajduje się tutaj istotnie w bardzo ciężkim położeniu materjalnem i wobec nieuchronnego skazania jej męża przez sąd na dłuższe więzienie znaleźć się może wraz z dziećmi w skrajnej nędzy”. Ponadto - jak pisał konsul - „p. Powolna oświadczyła, że nosi się z zamiarem rozwiedzenia się z mężem i ewentualnego powrotu do swego

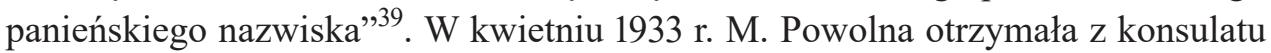
zasiłek w wysokości $100 \mathrm{RM}^{40}$.

Dnia 3 maja 1933 r. odbyła się rozprawa przeciwko L. Powolnemu, byłemu członkowi zarządu Banku Ludowego w Opolu. W akcie oskarżenia zarzucono Powolnemu dopuszczenie się trzech przestępstw: sprzeniewierzenia, fałszowania ksiąg i obejścia przepisów dotyczących konkursu (Konkursvergehen). Wysokość sprzeniewierzonej sumy według aktu oskarżenia wynosiła 78000 marek. Prokurator żądał kary w wysokości 1,5 roku więzienia i 10000 marek grzywny ${ }^{41}$. Ostatecznie sąd wymierzył karę 1 roku pozbawienia wolności z zaliczeniem aresztu prewencyjnego oraz 2000 marek grzywny z możliwością zamiany grzywny na

${ }^{36}$ Pismo Poselstwa RP w Berlinie do konsula generalnego RP w Opolu z 17 grudnia 1932 r. (T. 5000/32), tajne, tamże, k. 87.

${ }^{37}$ Odręczna notatka niepewnego autorstwa (prawdopodobnie konsula Malhomme'a) z 17 stycznia 1933 r., tajne, bez numeru, tamże, k. 88.

${ }^{38}$ Odpis pisma Konsulatu Generalnego RP w Opolu do Poselstwa RP w Berlinie z 25 marca 1933 r. (3483e/11/10), tajne, tamże, k. 89.

39 Tamże.

${ }^{40}$ Odręczny list M. Powolnej do konsula RP w Opolu z 14 kwietnia 1933 r., bez numeru, tamże, k. 91.

${ }^{41}$ Pismo konsula Bohdana Samborskiego do Poselstwa RP w Berlinie z 5 maja 1933 r. (297/N/ IV/2), tajne, tamże, k. 92. 
areszt według stosunku 1 dzień aresztu za 50 marek. Sąd uznał, że nie ma ryzyka ucieczki skazanego, zatem wypuścił Powolnego na „wolną stopę” wskazując na przysługujące mu w przepisanym terminie środki odwoławcze. Konsul relacjonując te wydarzenia stwierdził, że „sąd niemiecki przy rozprawie nie podnosił w najmniejszej mierze momentów politycznych, również prokurator w swej mowie nie ujawniał żadnych aluzyj, do których sprawa niniejsza z natury rzeczy mogłaby dać dość szerokie pole" ${ }^{\prime 2}$. Postulował także, aby Powolny po odsiedzeniu kary został „usunięty z tutejszego terenu”. Jednocześnie popierał otrzymanie przez jego żonę posady nauczycielskiej wśród emigracji polskiej poza terenem Niemiec.

Wyrok w sprawie Powolnego wywołał żywy oddźwięk w prasie śląskiej. Dnia 9 maja 1933 r. konsul Samborski przesłał Poselstwu RP w Berlinie streszczenie najważniejszych wypowiedzi ${ }^{43}$. Otóż brak 79000 mkn (marek niemieckich) oskarżony thumaczył niedopatrzeniem spowodowanym przepracowaniem. Odpierał stanowczo zarzut malwersacji, gdyż zarabiając $900 \mathrm{mkn}$ miesięcznie posiadał wystarczające środki materialne do utrzymania siebie i rodziny. Braki kasowe mogły być - według niego - spowodowane fałszywym księgowaniem wpływów i stratami poniesionymi przez bank. Ponadto podsądny wyraził przypuszczenie, że kluczem do kasy mógł posługiwać się ktoś inny, ponieważ Powolny zagubił go kilka lata temu. Tenże w toku rozprawy wyjaśnił, że udzielał w swoim czasie pożyczek, których nie księgował, gdyż udzielał ich wbrew woli rady nadzorczej banku. Posiadał na potwierdzenie tych transakcji kwity, które jednak zaginęły, nie może więc sobie przypomnieć nazwisk dłużników. W sprawie samochodu zakupionego za 7000 mkn Powolny oświadczył, że miał on służyć dla celów propagandowych, w związku z czym w części miał go sfinansować ZPwN. Licząc na to, Powolny otworzył sobie kredyt, jednak ostatecznie to on sam musiał pokryć całe koszty zakupu wozu, gdyż związek wycofał się jakoby „wskutek spadku liczby głosów polskich".

Oskarżony przyznał się natomiast do fałszywego księgowania. Dyrektor Banku Polskiego Spychalski oświadczył, że Powolny pracował w tej instytucji od $1907 \mathrm{r}$. i do roku 1930 nie stwarzał żadnych problemów.

Występujący w charakterze rzeczoznawcy dyrektor banku (innego) D. Sydow oświadczył, że „wszystkie książki banku prowadzone były w sposób skandaliczny, tak, że w niektórych wypadkach nie mógł on sam z powodu nieporządku zorien-

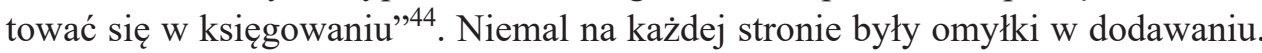

\footnotetext{
${ }^{42}$ Tamże.

${ }^{43}$ Pismo konsula Bohdana Samborskiego do Poselstwa RP w Berlinie z 9 maja 1933 r. (297/N/ IV/3), tajne, tamże, k. 94.

${ }^{44}$ Tamże.
} 
Zupełnie niewystarczające były kontrole Rady Nadzorczej, co znacznie opóźniło wykrycie sprzeniewierzenia.

W połowie czerwca 1933 r. powrócono do sprawy znalezienia zatrudniania dla M. Powolnej ${ }^{45}$. Zwróciła się ona bowiem ponownie o przyznanie jej posady nauczycielskiej, tym razem już w Polsce, wobec niemożności uzyskania takowej na „terenie niemieckim”46. W końcu lipca konsul generalny RP w Opolu otrzymał od Poselstwa RP w Berlinie informację, że „MWRiOP poleciło Kuratorium Okręgu Szkolnego Poznańskiego zatrudnić p. Martę Powolną w szkolnictwie w Polsce" ${ }^{\text {47 }}$. Wreszcie 4 listopada 1933 r., po wymianie wielu pism wyjaśniających i ponaglających, Poselstwo RP zawiadomiło opolski konsulat, iż p. Powolna ma „niezwłocznie zgłosić się u inspektora szkolnego w Koźminie celem objęcia posady nauczycielskiej”48. Dnia 8 listopada Kuratorium Okręgu Szkolnego Poznańskiego zawiadomiło Konsulat w Opolu, że „Powolna ma się zgłosić natychmiast u inspektora szkolnego w Ostrzeszowie"49. Z kolei w o dzień wcześniejszym piśmie kuratorium poznańskiego do Konsulatu w Opolu znajdujemy informację, że dla M. Powolnej zarezerwowano posadę nauczycielki kontraktowej w 3-klasowej publicznej szkole podstawowej w Polskich Olędrach w powiecie krotoszyńskim ${ }^{50}$.

Dnia 1 grudnia 1933 r. Konsulat Generalny RP w Opolu wystąpił do Dyrekcji Ceł w Poznaniu o zezwolenie na zwolnienie z opłaty celnej rzeczy ruchomych należących do M. Powolnej, która przesiedlała się do Polski i 10 grudnia tegoż roku miała objąć wreszcie posadę w Polskich Olędrach ${ }^{51}$. Dnia 5 grudnia 1933 r. poznańska Dyrekcja Ceł upoważniła Urząd Celny w Zdunach do „wykonania wolnej od cła odprawy używanych rzeczy przesiedlenia [...] stanowiących własność Marii Marty Powolnej stale osiedlającej się w miejscowości Koźmin ${ }^{52}$ powiatu

${ }^{45}$ Pismo konsula Bohdana Samborskiego do Poselstwa RP w Berlinie z 17 czerwca 1933 r. (297/N/IV/4), tajne, tamże, k. 94.

${ }^{46}$ Odręczny list m. Powolnej do MWRiOP w Warszawie z 16 czerwca 1933 r., bez numeru, tamże, k. 106.

${ }^{47}$ Pismo Poselstwa Polskiego w Berlinie do konsula generalnego RP w Opolu z 28 lipca 1933 r. (N/298/b/161), tajne, tamże, k. 110.

${ }^{48}$ Pismo Poselstwa Polskiego w Berlinie do konsula generalnego RP w Opolu z 4 listopada 1933 r. (N/298/b/272), tajne, tamże, k. 114.

${ }^{49}$ Telegram Kuratorium Okręgu Szkolnego Poznańskiego do Konsulatu Generalnego RP w Opolu z 8 listopada 1933 r., bez numeru, tamże, k. 115.

${ }^{50}$ Pismo Kuratorium Okręgu Szkolnego Poznańskiego do Konsulatu Generalnego RP w Opolu z 7 listopada 1933 r. (505/33. Tjn.), tajne, tamże, k. 117.

${ }^{51}$ Odpis pisma Konsulatu Generalnego RP w Opolu do Dyrekcji Ceł w Poznaniu z 1 grudnia 1933 r. (294/N/IV - 12), tamże, k. 118.

${ }^{52}$ Obecnie Koźmin Wielkopolski, zob. https://pl.wikipedia.org/wiki/Ko\%C5\%BAmin_Wielkopolski [dostęp: 9.04.2019]. 


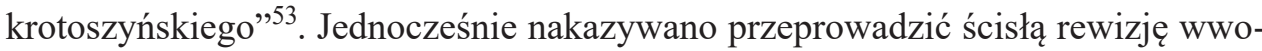
żonych rzeczy, gdyż w przypadku, gdyby między rzeczami używanymi znalazły się nowe, należało pobrać za nie „bezwzględnie przypadające opłaty celne" ${ }^{\text {54 }}$.

Dnia 27 września 1934 r. - a zatem, jak się wydaje, po odsiedzeniu kary - L. Powolny skierował do Konsulatu Generalnego RP w Opolu obszerny list ${ }^{55}$ w którym skarżył się, że oficjalnie odmówiono mu wizy do Polski. Nie podano mu także przyczyny tej odmowy, jednak wiązał ją on z jakąś sprawą sądową o zapłacenie długów, którą wytoczył niejakiemu panu Szczepaniakowi, pracownikowi ZPwN. Niewątpliwie był to ciąg dalszy sprawy wyżej opisanej malwersacji.

$\mathrm{Na}$ tym kończą się dokumenty dotyczące sprawy Powolnego, które na potrzeby niniejszego artykułu zostały przebadane.

\section{ZAKOŃCZENIE}

W opinii konsula Malhomme’a m.in. „nadużycia Powolnego” miały wpływ na coraz gorsze wyniki wyborcze mniejszości polskiej na Śląsku Opolskim, a także utrudniały prace „nad wytworzeniem elity kierowniczej”, której tak brakowało tutejszym Polakom ${ }^{56}$. Istniały podejrzenia, że „sprawa Powolnego” wpisywała się w niemiecką akcję przeciwko polskiej inteligencji, gdyż właśnie w okresie od 11 marca do 11 kwietnia 1933 r. ,polska służba konsularna w Opolu odnotowała aż 86 przypadków wystąpień przeciwko Polakom ${ }^{57}$ oraz 16 przypadków terroru wobec polskich Żydów"58. Odebrano także wtedy praktykę lekarską J. Kwoczkowi, jedynemu polskiemu lekarzowi prowincji śląskiej. Czy zatem Powolny padł ofiarą niemieckiej akcji odwetowej lub prowokacji? Moim zdaniem nie.

Można także zapytać, czy L. Powolny, podobnie jak duże grono polskich działaczy w Niemczech, był współpracownikiem lub funkcjonariuszem Oddziału II Sztabu Generalnego Wojska Polskiego, zajmującego się m.in. wywiadem i kontrwywiadem. Wiadomo, że np. konsul Malhomme otrzymał nominację za przyzwoleniem dyrektora Departamentu Konsularnego MSZ, z którego pomocy

${ }^{53}$ Odpis pisma Dyrekcji Ceł w Poznaniu do Urzędu Celnego w Zdunach z 5 grudnia 1933 r. (11-48), AAN, KGO, sygn. 2/482/0/4/153, k. 120.

${ }^{54}$ Tamże.

${ }^{55}$ List Leona Powolnego do Konsulatu Generalnego RP w Opolu z 27 września 1934 r., bez numeru, tamże, k. $121 \mathrm{n}$.

${ }^{56}$ MasnyK, Dzielnica I Związku Polaków w Niemczech, s. 178.

57 Tamże, s. 194.

${ }^{58}$ F. PoŁomsKi, Położenie ludności żydowskiej na Ślasku po dojściu Hitlera do władzy, „Studia Śląskie" 11 (1967), s. 55-72. 
korzystała warszawska Ekspozytura nr 2, będąca „emanacją” „dwójki”, ${ }^{59}$. Sprawy te domagają się szczegółowego zbadania, jednak należy raczej wykluczyć, aby Powolny dokonał defraudacji na polecenie (bądź chociażby za wiedzą) polskiego wywiadu lub kontrwywiadu. Sprawie polskiej na Śląsku Opolskim nie przysłużyło się to w żadnej mierze - sam Malhomme ubolewał z powodu „nadużyć Powolnego", o czym wspomniano wyżej.

Co zatem powodowało Leonem Powolnym? W pełni wiedział to oczywiście tylko on sam, jednak wydaje się, że dopuszczenie się defraudacji było jego własnym pomysłem. Dodać tutaj należy, że przypadek Powolnego nie był wcale odosobniony. Mniej więcej w tym samym czasie podobnej malwersacji dokonał dr Klemens Śliwiński, dyrektor Banku Rolników w Opolu, instytucji ściśle współpracującej z Bankiem Ludowym, w którym pracował Powolny ${ }^{60}$. Ukradł on 26731,60 zł i 4 000,00 RM, a jego rozprawa sądowa miała miejsce 9 marca 1932 r. w Katowicach ${ }^{61}$. W 1931 r. wyszła na jaw malwersacja dokonana przez Eryka Wyciska, kasjera Banku Ludowego w Raciborzu, współpracującego w przestępczym procederze z niejakim Józefem Warzechą ${ }^{62}$. Rozważano skierowanie tej sprawy do sądu, gdyż jak argumentowano: „Za wytoczeniem procesu przemawia ta okoliczność, że bezkarność nadużyć popełnionych $\mathrm{w}$ instytucji polskiej w Niemczech jest fatalnym przykładem, zachęcającym do nieuczciwości elementy mniej odporne moralnie"63. Jednakże zdawano sobie sprawę z tego, iż „przeciw wytoczeniu postępowania sądowego przemawia to, że ewentualne wkroczenie prokuratora niemieckiego i zażądanie przez niego ksiąg i korespondencji Banku Ludowego w Raciborzu może dać władzom niemieckim do rąk materiały dotyczące kredytów płynących z Polski, a być może także informacje o pomocy materialnej o charakterze subwencyjnym, gdyż na ostrożności polskich instytucji w Niemczech polegać pod tym względem nie można" ${ }^{64}$. W. Jędrzejewicz, dyrektor Departamentu Konsularnego MSZ w Warszawie, przychylał się do odstąpienia od wdrożenia dochodzeń sądowych przeciwko defraudantom ,ze względu na wybitnie polityczny charakter sprawy" ${ }^{65}$. Ostatecznie do wytoczenia sprawy nie doszło, a sprawcy nie zostali ukarani.

Na podobną bezkarność mógł zapewne liczyć Powolny, co jednak ostatecznie się nie zdarzyło, gdyż został pociągnięty do odpowiedzialności. Z pewnością jed-

\footnotetext{
${ }^{59}$ Masnyk, Dzielnica I Związu Polaków w Niemczech, s. 216 n.

${ }^{60}$ Zob. AAN, KGO, sygn. 2/482/0/4/153, k. 15.

${ }^{61}$ Tamże, k. 24.

${ }^{62}$ Tamże, k. 30 n.

${ }^{63}$ Tamże, k. 31.

${ }^{64}$ Tamże, k. 32.

${ }^{65}$ Pismo dyrektora Wydziału Konsularnego MSZ w Warszawie do Konsulatu Generalnego RP w Bytomiu z 10 lipca 1931 r. (1030/T/31.), tajne, tamże, k. 34.
} 
nak taka możliwość osłabiała jego „odporność moralną”. Ponadto zatrudniający go bank miał wobec niego znaczne zobowiązania finansowe, wobec czego defraudant mógł dojść do wniosku, że sam sobie może przecież „wypłacić” należne mu kwoty. Jako dyrektor instytucji mógł uczynić to z łatwością, pozostając praktycznie poza kręgiem podejrzanych. Oczywiście do czasu. Te i inne zapewne przyczyny spowodowały, że wybitny działacz narodowy stał się złodziejem, po to, aby po pewnym czasie znowu stać się autentycznie nieugiętym bojownikiem sprawy polskiej, za nią ponieść męczeńską śmierć i jako bohater przejść do historii. Któż wie, co mieszka w człowieku?

\section{BIBLIOGRAFIA}

Choroś Monika, JARCZaK Łucja: Ludzie i historia w nazwach ulic Opola, Opole: Wydawnictwo Instytutu Śląskiego 2010.

CygaŃski Mirosław: Hitlerowskie prześladowania przywódców i aktywu Związku Polaków w Niemczech w latach 1939-1945, Przeglad Zachodni 4 (1984), s. 23-64.

Dermin Ryszard: Działacze Związku Polaków w Niemczech na Śląsku Opolskim w kartotece opolskiego gestapo, Studia Śląskie 22 (1972), seria nowa, s. 205-252, [w:] https://view.publitas.com/ pin-instytut-slaski/studia-slaskie-t-22/page/8-9 [dostęp: 28.05.2019].

Kempa Wojciech: Armia Krajowa na Opolszczyźnie (część pierwsza), [w:] https:/www.magnapolonia. org/armia-krajowa-na-opolszczyznie-czesc-pierwsza/ [dostęp: 24.04.2019].

KuŹNIEwsKi Ignacy [i in.]: Ulice Opola. Sylwetki zasłużonych Opolan, Opole: Opolskie Zakłady Graficzne 1971.

Lehr Helena, Osmańczyk Edmund J.: Polacy spod znaku Rodła, Warszawa: Wydawnictwo Ministerstwa Obrony Narodowej 1972.

MASNYK Marek: Dzielnica I Związku Polaków w Niemczech (1923-1939), Opole: Wyższa Szkoła Pedagogiczna 1994.

OsmańcZYK Edmund J.: Wisła i Kraków to Rodło, Warszawa: Wydawnictwo Nasza Księgarnia 1985.

PoŁomski Franciszek: Położenie ludności żydowskiej na Śląsku po dojściu Hitlera do władzy, Studia Śląskie 11 (1967), s. 55-72.

SENFT Stanisław: Warunki niezależności ekonomicznej mniejszości polskiej na Śląsku Opolskim, Pogranicze. Polish Borderlands Studies 1 (3) 2015, s. 57-67.

\section{LEON POWOLNY. BOHATER WALKI O POLSKOŚĆ ŚLĄSKA OPOLSKIEGO CZY DEFRAUDANT?}

\section{Streszczenie}

W artykule Leon Powolny. Bohater walki o polskość Śląska Opolskiego czy defraudant? ukazano jeden z mniej znanych epizodów z życia tego zasłużonego bojownika o polskość Śląska Opolskiego. Powolny - jak wskazują na to materiały źródłowe - był także złodziejem, defraudantem, który okradł bank, w którym pracował. Przez niemiecki wymiar sprawiedliwości skazany został na karę więzienia i tę najprawdopodobniej odbył. Po czym dalej funkcjonował w ruchu mniejszościowym 
na eksponowanych stanowiskach, był dowódcą struktur konspiracyjnych podczas II wojny światowej i zginął śmiercią męczeńską w niemieckim więzieniu w Brandenburgu, gdzie ścięto mu głowę toporem. Na pytanie, jak można było pogodzić te dwie postawy, autor z pokorą odpowiada: nie wiem! Być może szerzej zakrojone badania archiwalne pozwolą odpowiedzieć na tak postawione pytanie.

Słowa kluczowe: Leon Powolny; Śląsk Opolski; Związek Polaków w Niemczech; defraudacja; Bank Ludowy

\section{LEON POWOLNY. HERO OF FIGHT FOR POLISHNESS OF OPOLE SILESIA OR DEFRAUDER?}

\section{Sum mary}

In the paper „Leon Powolny. Hero of fight for Polishness of Opole Silesia or defrauder?” one of fewer known episodes was presented from the honoured fighter for the Polishness of Opole Silesia. Leon Powolny - as the source materials indicate - was also a thief, defrauder who robbed the bank in which he worked. By the German jurisdiction he was sentenced to imprisonment and he most likely served that sentence. Afterwards he functioned in the minority movement at exposed posts, he was a commander of the conspiracy structures during the Second World War and he died a martyr's death in the German prison in Brandenburg where his head was cut off by means of an axe. On the question how to bring together those two attitudes, the author with humility answers: I do not know! Perhaps wider developed archive research will allow replying such a question asked.

Key words: Leon Powolny; Opole Silesia; Association of Poles in Germany; embezzlement; People's Bank 